ORGANIZATION THEORY AND THE MULTINATIONAL CORPORATION 


\section{Organization Theory and the Multinational Corporation}

Edited by

Sumantra Ghoshal

Associate Professor

and Digital Equipment Corporation Research Fellow at INSEAD, Fontainebleau, France

and

D. Eleanor Westney

Associate Professor of Management at

Sloan School of Management

Cambridge, Massachusetts, USA

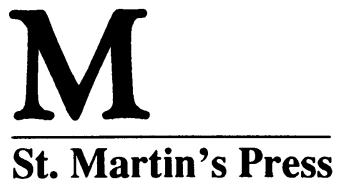


Selection, editorial matter and introduction $\odot$ Sumantra Ghoshal and

D. Eleanor Westney 1993

Chapter 2 @ Yves Doz and C. K. Prahalad 1993; Chapter 3 @ D. Eleanor

Westney 1993; Chapter 4 @ Sumantra Ghoshal and Christopher Bartlett 1993;

Chapter 5 @ Jacques Delacroix 1993; Chapter 6 @ Bruce Kogut 1993; Chapter 7

(C) Jean-François Hennart 1993; Chapter 8 @ William Egelhoff 1993; Chapter 9

(c) Gunnar Hedlund 1993; Chapter 10 @ W. Chan Kim and Renée Mauborgne

1993; Chapter 11 @ Martin Kilduff 1993; Chapter $12 @$ John Van Maanen and

André Laurent 1993

Softcover reprint of the hardcover 1st edition 1993 978-0-333-54622-2

All rights reserved. No reproduction, copy or transmission of this publication may be made without written permission.

No paragraph of this publication may be reproduced, copied or transmitted save with written permission or in accordance with the provisions of the Copyright, Designs and Patents Act 1988, or under the terms of any licence permitting limited copying issued by the Copyright Licensing Agency, 90 Tottenham Court Road, London W1P 9HE.

Any person who does any unauthorised act in relation to this publication may be liable to criminal prosecution and civil claims for damages.

First published in Great Britain 1993 by

THE MACMILLAN PRESS LTD

Houndmills, Basingstoke, Hampshire RG21 2XS

and London

Companies and representatives

throughout the world

A catalogue record for this book is available from the British Library.

ISBN 978-1-349-22559-0 ISBN 978-1-349-22557-6 (eBook)

DOI 10.1007/978-1-349-22557-6

Reprinted 1993

First published in the United States of America 1993 by

Scholarly and Reference Division,

ST. MARTIN'S PRESS, INC.,

175 Fifth Avenue,

New York, N.Y. 10010

Library of Congress Cataloging-in-Publication Data

Organization theory and the multinational corporation/edited by

Sumantra Ghoshal and D. Eleanor Westney.

p. $\mathrm{cm}$.

Includes index.

1. International business enterprises-Management.

2. Organization. 3. Organizational behavior. 4. Corporate culture.

I. Ghoshal, Sumantra. II. Westney, D. Eleanor.

HD62.4.074 1993

338.8 ' $-\mathrm{dc} 20$ 


\section{Contents}

List of Tables and Figures vii

Acknowledgements viii

Notes on the Contributors $\quad \mathrm{x}$

1 Introduction and Overview 1

Sumantra Ghoshal and D. Eleanor Westney

2 Managing DMNCs: A Search for a New Paradigm 24

Yves Doz and C. K. Prahalad

Part I Environment and Organization-Environment Interactions 51

3 Institutionalization Theory and the Multinational

Corporation $\quad 53$

D. Eleanor Westney

4 The Multinational Corporation as an Interorganizational

Network

Sumantra Ghoshal and Christopher Bartlett

5 The European Subsidiaries of American Multinationals: An Exercise in Ecological Analysis

Jacques Delacroix

6 Learning, or the Importance of being Inert: Country

Imprinting and International Competition

136

Bruce Kogut

Part II Organization Structure and Governance

7 Control in Multinational Firms: The Role of Price and Hierarchy

Jean-François Hennart

8 Information Processing Theory and the Multinational

Corporation

William Egelhoff

9 Assumptions of Hierarchy and Heterarchy, with

Applications to the Management of the Multinational

Corporation

Gunnar Hedlund 
10 Procedural Justice Theory and the Multinational Corporation

W. Chan Kim and Renée Mauborgne

Part III Organizational Culture and Norms 257

11 The Reproduction of Inertia in Multinational Corporations 259 Martin Kilduff

12 The Flow of Culture: Some Notes on Globalization and the Multinational Corporation

John Van Maanen and André Laurent

References

Index 


\section{List of Tables and Figures}

\section{Tables}

2.1 The relevance of organization theories to DMNC management research $\quad 32$

4.1 Different contexts of interorganizational interactions 84

5.1 Maximum likelihood estimations 126

6.1 Total and foreign entries in the USA 153

$\begin{array}{lll}7.1 & \text { Employee control modes used in firms } & 167\end{array}$

7.2 Subunit control modes used in firms 171

7.3 Correlations between centralization scales and strategic and environmental conditions 177

8.1 Location of information-processing capacity in the four elementary MNC structures

\section{Figures}

2.1 Levels of aggregation and theory development

4.1 Organizational units and some of the interlinkages within N.V. Philips

4.2 Centrality measures for three different network structures (reproduced from Freeman 1979)

5.1 Number of subsidiaries in simultaneous existence, 190373

5.2 Number of subsidiary foundings, 1903-73

5.3 Number of subsidiary disbandings, 1903-73 120

$\begin{array}{lll}5.4 & \text { France and Spain } & 122\end{array}$

5.5 Germany and the UK 122

5.6 Netherlands and Portugal 123

5.7 Belgium and Austria 123

8.1 The general information-processing approach to
organizational design

8.2 The structural dimensions of information processing 193

8.3 The process dimensions of MNC information processing 195

8.4 The capacities of information-processing mechanisms 200

10.1 Relations among procedural justice, strategic decision outcomes, high-order attitudes and outcome satisfaction 


\section{Acknowledgements}

This volume had its origins in a panel for the annual meeting of the Academy of International Business in San Diego in October 1988. The Chair of the program, Donald Lessard, had chosen as the meeting's theme the challenge of building a stronger discipline-grounded theory base for future research in the field of international business. At his prodding, the two editors of this volume joined forces with Bill Egelhoff to organize a panel on 'Organization Theory and the Multinational Corporation'. The response from our colleagues persuaded all three of us that the topic warranted further development. We decided to pursue it by bringing together the scholars from the international business field who were working on organizational issues concerning the multinational corporation (MNC) and an equivalent number of organization theorists to explore together the potential contributions each field could make to the other.

We were fortunate to engage the interest of a number of leading contributors to both fields, who joined us at a Workshop on Organization Theory and the Multinational Corporation, held at INSEAD on 1 and 2 September 1989. The contributors to this volume - most but not all of whom are primarily researchers in the international business field agreed to write papers that explored the potential synergies between the two fields. A number of leading organization theorists agreed to provide advance feedback to the authors and to serve as discussants for the workshop and as a collective resource for the overall project. Most of the time at the workshop itself was spent in small group discussions on the papers, and these discussions provided a further basis for the extensive revisions that produced the work included in this volume.

As editors, therefore, we owe our greatest debt of gratitude to the participants in the workshop: Howard Aldrich, Christopher Bartlett, John Daniels, Jacques Delocroix, Yves Doz, William Egelhoff, Cathy Enz, Michael Gerlach, Gunnar Hedlund, Jean François Hennart, Carlos Jarillo, Martin Kilduff, W. Chan Kim, John Kimberly, Bruce Kogut, Mitchell Koza, André Laurent, W. Richard Scott, Andrew Van de Ven, David Whetten and Sidney Winter. However, many other hands also lightened our tasks. Four of INSEAD's doctoral students acted as rapporteurs, providing the authors with detailed notes on the discussions: Carlos Cordon, Dana Hyde, Harry Korine and Gabriel Szulanski. Ruth Lewis of INSEAD managed the complex logistics of the workshop with unflurried competence and grace. Loretta Caira and Vaira Harik at 
MIT provided invaluable help in preparing the manuscript, and Patricia Robinson aided the preparation of the lengthy bibliography. Our editors have proven to be extremely patient and understanding as one selfimposed deadline after another receded into the distance.

Finally, we wish to acknowledge the unstinting support - both administrative and financial - that we have received from INSEAD. We are particularly grateful to Ludo Van der Heyden, INSEAD's Associate Dean for Research at the time of the workshop and now its Co-Dean, who shared our enthusiasm for the project and provided the support that made it possible.

The participants in the workshop were virtually unanimous in expressing the hope that it would be followed by further opportunities for dialogue between the two research communities. We hope that this volume represents only the first step in the ongoing process.

SUMANTRA GHOSHAL

D. ELEANOR WESTNEY 


\section{Notes on the Contributors}

Christopher Bartlett is Professor of Business Administration at the Graduate School of Business, Harvard University. He received an economics degree from the University of Queensland, Australia, and both a masters and a doctorate degree in business administration from Harvard. Prior to his advanced graduate studies he worked as a marketing manager with Alcoa, as a management consultant with McKinsey \& Company's London office, and as general manager of Baxter Laboratories' subsidiary in France. His publications have appeared in the Harvard Business Review, the Sloan Management Review and the Human Resource Management Journal, among others. $\mathrm{He}$ is the author of Managing Across Borders: The Transnational Solution (with Sumantra Ghoshal) and co-editor of Managing the Global Firm. His interests have focused on the general management challenges facing large complex corporations.

Jacques Delacroix is currently an Associate Professor in the Leavey School of Business Administration at Santa Clara University. A native of France, Jacques Delacroix emigrated to the USA in 1963 and obtained his $\mathrm{PhD}$ from Stanford in 1974. From 1974 to 1978 he taught at Indiana University; from 1978 to 1983 he founded and managed an international business consulting company in San Francisco; in 1983 he joined the faculty of the business school at Santa Clara University in California. His recent research on organizational ecology has been published in the American Sociological Review, the American Journal of Sociology and Administrative Science Quarterly. His current interests centre on the application of the methods of organizational ecology to international management issues.

Yves Doz is the John H. Loudon Professor of International Management and Associate Dean for Research at INSEAD. He is a graduate of the Ecole des Hautes Etudes Commerciales (Jouy-en-Josas, France) and received his doctoral degree from the Harvard Business School, where he was an assistant professor from 1976 to 1979. His research on the strategy of MNCs, focusing particularly on high-technology industries, led to numerous publications, including three books: Government Control and Multinational Management (1979); Strategic Management in Multinational Companies (1986); and The Multinational Mission: Balancing Local Demands and Global Vision (with C. K. Prahalad, 1987). His 
research interests also include innovation and entrepreneurship in large, complex firms, and strategic partnerships and technological cooperation between companies.

William G. Egelhoff is Associate Professor of Management Systems at the Graduate School of Business, Fordham University. Previously he was on the faculty at New York University. He received his $\mathrm{PhD}$ and MBA degrees from Columbia University, and his undergraduate degree from the University of Texas. Prior to returning for his PhD, he worked in various planning positions with Esso and the National Distillers and Chemicals Corporation. His research deals with strategy and organizational design in MNCs. He has written a number of articles in this area and also a book entitled Organizing the Multinational Corporation: An Information-Processing Perspective.

Sumantra Ghoshal is Associate Professor of Management and Digital Equipment Corporation Research Fellow at INSEAD. He received his doctoral degrees in international management from MIT's Sloan School of Management and in business policy from the Harvard Business School. His research interests focus on the strategic and organizational challenges facing large, complex organizations, particularly multinational companies, and his articles have appeared in the Harvard Business Review, Sloan Management Review, Strategic Management Journal, Journal of International Business Studies, California Management Review, McKinsey Quarterly and Academy of Management Review. He has written two books: Strategic Control (co-authored with Peter Lorange and Michael S. Scott Morton); and Managing Across Borders: The Transnational Solution (co-authored with Christopher A. Bartlett).

Gunnar Hedlund is a Professor of Business Administration at the Stockholm School of Economics, and he has been a visiting scholar at the Wharton School, the European Institute for Advanced Studies in Management in Brussels, and the Graduate School of Business at Stanford University. His publications have appeared in Strategic Management Journal and Human Resource Management and, with Christopher Bartlett and Yves Doz, he edited Managing the Global Firm (1988).

Jean-François Hennart is Associate Professor of International Business at the University of Illinois at Urbana-Champaign. He received his $\mathrm{PhD}$ degree in Economics from the University of Maryland. He is the author of $A$ Theory of Multinational Enterprise and has published extensively on transaction cost approaches to the international business firm, joint 
ventures and countertrade in such journals as Management Science, Journal of International Business Studies and Strategic Management Journal.

Martin Kilduff is currently an Assistant Professor of Organizational Behaviour in the Management and Organization Department at Pennsylvania State University. He received his $\mathrm{PhD}$ degree in organizational behaviour from Cornell University and until 1990 was a member of the faculty in the organization behaviour group at INSEAD. Recent publications have appeared in American Anthropologist and in Organizational Behaviour and Human Decision Processes (1991, edited by John Carroll). His current research includes a social network study of team interaction and productivity in Japanese factories (with Mark Fruin) and an investigation of cultural differences in institutionalization (with Reinhard Angelmar).

W. Chan Kim is Assistant Professor of Business Policy at INSEAD, which he joined after teaching at the University of Michigan, where he received his $\mathrm{PhD}$ in international management. He has published various articles in the area of global strategy, and economic and organizational analysis of multinational enterprises in such journals as Sloan Management Review, Journal of International Business Studies, Strategic Management Journal, Management Science and Journal of Business Strategy.

Bruce Kogut, who received his PhD from MIT in 1983, is Associate Professor of Management at the Wharton School and has been a visiting scholar at the Stockholm School of Economics, Science Center, and Academy of Sciences in Berlin. He has published on country competitiveness, the operating flexibility of the MNC, and the theory of foreign direct investment in such journals as the Sloan Management Review, the Journal of International Business Studies, and the Strategic Management Journal. His current work is on the internationalization of national industrial networks and the international diffusion of best practice.

André Laurent is Professor of Organizational Behaviour at INSEAD. He is a graduate of the Ecole de Psychologues Praticiens de Paris at the University of Paris - Sorbonne (with a degree in Sociology and a doctorate in Psychology) and of Harvard University's International Teachers' Program. He was an industrial psychologist with Pechiney in West Africa and spent three years with the Institute for Social Research at the University of Michigan as Research Associate and Study Director before joining INSEAD. His major research interests centre on the 
impact of national cultures on organizations and the management of cultural diversity in multinational firms.

Renée Mauborgne is Research Associate at INSEAD. Prior to joining INSEAD she was a Senior Consultant for Lux Management Associates in Greenwich, Connecticut. She has published several articles in the area of global strategy and the organizational aspects of the multinational enterprise in such journals as Strategic Management Journal and Journal of Business Strategy.

C. K. Prahalad is the Professor of Corporate Strategy and International Business at the Graduate School of Business Administration, University of Michigan, Ann Arbor. He received his BSc in Physics from the University of Madras, his MBA from the Indian Institute of Management, and his DBA from the Harvard Business School. He was Visiting Research Fellow at Harvard, Professor at the Indian Institute of Management, Ahmedabad, India, and Visiting Professor at INSEAD, France. His research and consulting interests centre around the role of top management in large, diversified MNCs. He has published widely on the subject in professional journals and has co-authored The Multinational Mission: Balancing Local Demands and Global Vision with Yves Doz (INSEAD, France), and his recent work on strategic intent and core competencies has been published in the Harvard Business Review.

John Van Maanen is the Erwin Scholl Professor of Organization Studies in the MIT Sloan School of Management. He has also taught at Yale University and has been a visiting member of various faculties for executive development programs, including the University of Hawaii and the University of Southern California. He has published a number of books and articles in the general area of occupational sociology. Cultural descriptions figure prominently in his studies of the work worlds of patrol officers on city streets in the USA; police detectives and their bosses in London; fishermen of the north-eastern Atlantic; and, currently, ride operators in Disneyland. His latest book is about ethnographic narratives and is entitled Tales of the Field.

D. Eleanor Westney is Associate Professor of Management at the MIT Sloan School of Management. She received a BA and an MA in Sociology from the University of Toronto and a PhD in Sociology from Princeton University. She has worked extensively on Japanese organizations, and is the author of Imitation and Innovation: The Transfer of Western Organizational Forms to Meiji Japan (Harvard University Press, 1987). Her research continues to focus on the 
processes of learning across borders, particularly in the context of the internationalization of $\mathrm{R} \& \mathrm{D}$ in large US, Japanese and European multinationals. 